
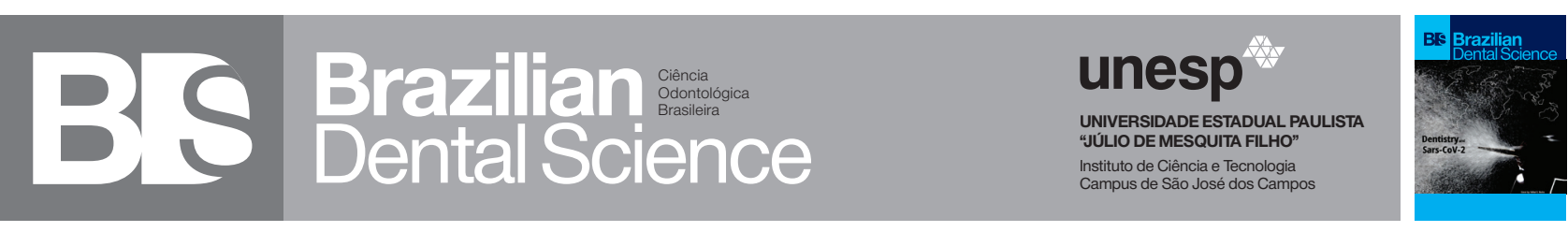

\title{
Knowledge, Awareness, and Practice of Dentists in Preventing- Novel Corona Virus (COVID-19) Transmission - A Questionnaire Based Cross-Sectional Survey
}

Conhecimento, consciência e prática de dentistas na prevenção da transmissão de novos vírus corona (COVID-19) - uma pesquisa transversal baseada em questionário

Kavalipurapu Venkata TEJA ${ }^{1}$, Kaligotla Apoorva VASUNDHARA², Gummuluri SRIRAM ${ }^{3}$

1 - Vishnu Dental College- Bheemavaram - India.

2 - Sibar Institute of Dental Sciences - Guntur - India.

3 - SVS Group of Institutions - SVS School of Pharmacy - Bheemaram - Hanumakonda - Warangal - Telangana - India.

\section{ABSTRACT}

Background: The global issue that urges the public health emergency is the outbreak of the Novel Corona Virus strain (COVID-19). Dentists being are highly prone to airborne transmission during dental treatment due to aerosols generated by various dental procedures on patients with COVID-19. Taking this fact into consideration, the present survey research was mainly aimed at evaluating the knowledge, attitude, and practice of dentists in preventing the disease transmission of Novel Coronavirus (COVID-19). Material and methods: The present study is prospective research, where the online survey questionnaire was distributed among 300 dentists in Andhra Pradesh and Telangana states in India, who were randomly recruited for the study. The participants were recruited based on the clinical experience ranging from less than five years to more than ten years, who were working in both the private and government sectors. 15 close-ended questions were formulated and validated. The questionnaire consisted of the necessary demographic details of the participants and equally distributed into three sections that contained questions that assessed the knowledge, attitude, and practice of dentists in preventing the disease transmission of Novel Coronavirus (COVID-19). Results: The results revealed that dentists have an adequate knowledge and awareness on COVID-19 transmission and most of the dentists felt that dentists have a major role in preventing the disease transmission. Majority of the participants raised the importance of awareness programs have to be conducted on various measures in preventing COVID-19 transmission among dental fraternity and

\section{RESUIMO}

Histórico: A questão global que instiga a emergência de saúde pública é o surto do Novel Corona Virus (COVID-19). Os dentistas são altamente propensos à transmissão aérea durante o tratamento dentário devido aos aerossóis gerados por vários procedimentos odontológicos em pacientes com COVID-19. Levando esse fato em consideração, a presente pesquisa teve como objetivo principal avaliar o conhecimento, a atitude e a prática dos dentistas na prevenção da transmissão da doença pelo novo coronavírus (COVID-19). Material e métodos: O presente estudo é uma pesquisa prospectiva, na qual o questionário online de pesquisa foi distribuído entre 300 dentistas, que foram recrutados aleatoriamente para o estudo, nos estados de Andhra Pradesh e Telangana, na Índia. Os participantes foram recrutados com base na experiência clínica que variava de menos de cinco anos até mais de dez anos, que trabalhavam nos setores privado e público. Quinze perguntas fechadas foram formuladas e validadas. O questionário consistiu nos detalhes demográficos dos participantes e três seções com distribuição igualitária, as quais continham perguntas que avaliavam o conhecimento, a atitude e a prática dos dentistas na prevenção da transmissão da doença pelo novo coronavírus (COVID-19). Resultados: Os resultados revelaram que os dentistas têm um conhecimento e conscientização adequados sobre a transmissão do COVID-19 e a maioria considerou que os dentistas têm um papel importante na prevenção da transmissão da doença. A maioria dos participantes levantou a importância de que programas de conscientização devem ser conduzidos sobre várias medidas para impedir a transmissão do COVID-19 entre a comunidade odontológica e com o público. Conclusões: 
in public. Conclusions: From the survey research it can be concluded that dentists have an adequate knowledge and awareness on COVID-19 disease. Majority of them are trying their level best in the present situation to prevent COVID-19 transmission.

\section{KEYWORDS}

COVID-19; Dentists; Infection control.
A partir da pesquisa realizada pode-se concluir que os dentistas possuem conhecimento e conscientização adequados sobre a doença de COVID-19. A maioria deles está contribuindo da melhor maneira possível na situação atual para impedir a transmissão do COVID-19.

\section{PALAVRAS-CHAVE}

COVID-19; Dentistas; Controle de infecção.

\section{INTRODUCTION}

$\mathrm{T}$ he global issue that urges the public health emergency is the outbreak of the Novel Corona Virus strain (COVID-19). [1] The symptoms of these outbreaks range from fever, cough, and an acute respiratory disease to severe life-threating respiratory infection, leading to pneumonia, kidney failure, and even death. [2] The severity of this respiratory illness first reported in Wuhan, Hubei, China, which has currently spread worldwide. [3] The genomic sequencing samples collected samples, suggest that viral emergence is related to bat coronaviruses. [4] The coronavirus infection in humans presents with different severities based on the type of infection. Although, mild severity was seen in humans with coronavirus infections, reported mortality rates were severe with beta coronavirus infection of either severe acute respiratory syndrome coronavirus (SARS-CoV) [5] or Middle East respiratory syndrome coronavirus (MERS-CoV). [6]

Currently, different routes of COVID-19 transmission have to be explored. But the transmission among humans has been confirmed. $[7,8]$ Several potential routes of COVID-19 transmission have been established via contact with droplets from talking, coughing, sneezing, or through aerosols generated during any clinical procedures, as similar to other respiratory infections. The larger viral droplets contribute to the transmission to nearby surroundings. In contrast, the smaller droplets tend to travel more considerable distances and transmit the infection to longer distances.[9] Although symptoms were seen in infected individuals, asymptomatic infections to seem to be possible, [10] and transmission may occur before the disease symptoms occur. Taking a fact from a recent clinical study in 138 hospitalized patients with COVID-19 in Wuhan, China, 29\% of them were health care workers. [11]
Dentists being are highly prone to airborne transmission during dental treatment due to aerosols generated by various dental procedures on patients with COVID-19. [12] In this context, as healthcare workers, dentists may be unknowingly providing the direct care to the infect but not yet diagnosed COVID-19 patients or those considered to be suspected cases for surveillance.[13] Taking this fact into consideration, the present survey research was mainly aimed at evaluating the knowledge, attitude, and practice of dentists in preventing the disease transmission of Novel Coronavirus (COVID-19).

\section{METHODOLOGY}

The present study is prospective research, where the online survey questionnaire was distributed among 300 dentists in Andhra Pradesh and Telangana states in India, who were randomly recruited for the study. The participants were recruited based on the clinical experience ranging from less than five years to more than ten years, who were working in both the private and government sectors. Out of 300 dentists, 180 were females, and 120 were males. 15 close-ended questions were formulated and validated. The questionnaire consisted of the necessary demographic details of the participants and equally distributed into three sections that contained questions that assessed the knowledge, attitude, and practice of dentists in preventing the disease transmission of Novel Coronavirus (COVID-19).

The collected data was analysed using IBM. SPSS Software 23.0 Version. To describe data, descriptive statistics like frequency and percentage analysis was used.

\section{Survey Questionnaire:}

1. Do you know that COVID-19 is pandemic and spread is mostly controllable if appropriate 
sanitisation and infection control is followed in dental practice?

A) yes b) no c) may be

2. According to you, which health care professionals are at higher risk of novel corona virus?

A) dental professionals b) paramedics c) nurses d) other health care professionals

3. Which source of information do you feel is reliable on obtaining knowledge about COVID-19?

A) Google b) You-Tube c) social media d) national health authorities \& who website

4. Do you feel the available source of information on COVID-19 is sufficient to prevent the disease transmission?

A) yes b) no c) might not be sufficient

5. Do you feel the national health authorities are able to control the spread of infection \& better to follow their instructions to prevent transmission?

A) yes b) no c) not sure

6. Which history of the patient you feel is more important, and you are concentrating the most, before proceeding to a dental treatment?

A) travel history b) history of chronic illness c) history of recent fever, malaise or susceptible symptoms d) all the above

7. Which personal protective equipment you feel is more important to protect yourself in preventing transmission?

A) mouth masks and head caps b) gloves, face shields, over coats, gowns and eye wear c) disinfectant solutions, sanitizers d) all the above

8. Do you face scarcity of any personal protective equipment? If yes, then which one do you feel is scarcer in the present situation?

A) mouth masks b) gloves c) other equipment's d) i don't feel any scarcity

9. What is the reason for the scarcity of this personal protective equipment's?

A) lack of availability b) higher cost c) increased usage by general population (especially mouth masks) d) no reason for scarcity
10. Which dental treatment procedures do you feel has more chances to transmit covid-19?

A) restorative procedures or any procedures producing aerosols b) surgical procedures c) orthodontic procedures d) prosthodontics procedures e) other minor dental treatment procedures

11. In the current scenario what treatment procedures you are practicing the most keeping in mind about COVID-19 transmission?

A) dental extractions b) emergency endodontic therapy c) oral surgeries d) oral prophylaxis e) crown preparations f) other dental treatments not listed g) only symptomatic management no interventional treatments

12. Do you feel dentist has a major role in educating the patients about the pandemic spread of COVID-19?

A) yes b) no c) not much

13. What do you feel is the role of dentist in the current situation in preventing the disease transmission?

A) educating patients on current situation to prevent disease transmission is more important than performing non-emergency procedures b) importance on educating patients about appropriate sources of information c) performing all dental procedures including emergency and elective d) delivering only emergency care which is required for the current situation e) i don't feel we do have a role in preventing the COVID-19 transmission

14. What is your conclusive remark on present situation?

A) don't be panic and follow national health authorities \& who guidelines b) perform all clinical procedures c) don't practice until everything comes under control d) postpone all non-emergency procedures until situation is under control

15. Do you feel that in the present situation we require more awareness programmes among dental fraternity and in the public on importance of various measures in preventing COVID-19 transmission?

A) definitely required b) not required c) required but through appropriate \& recognised sources 
Graphs: Depicting the Results of the Survey Questionnaire

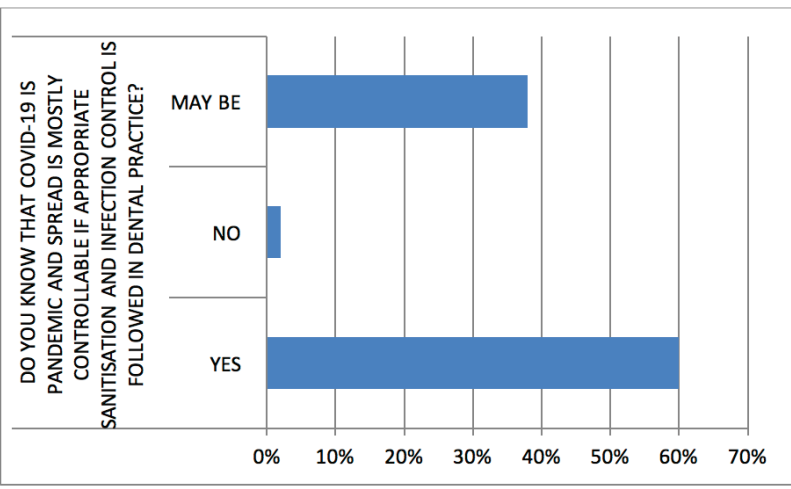

Graph 1 - Nature of disease and spread.

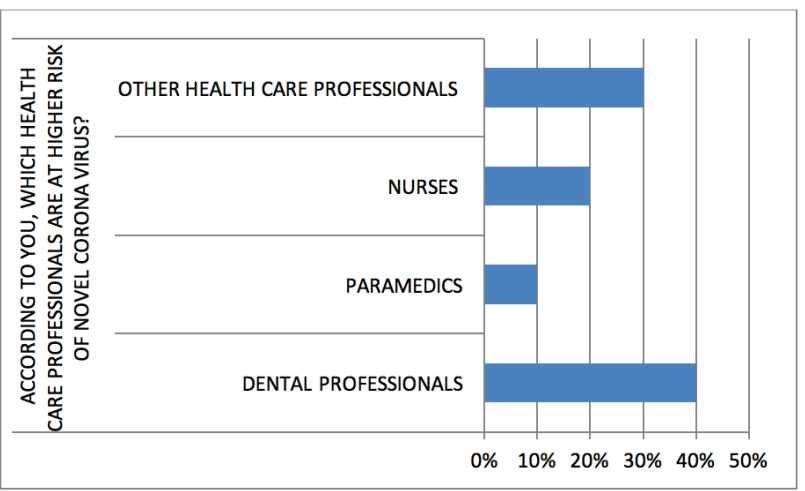

Graph 2 - Professionals at higher risk.

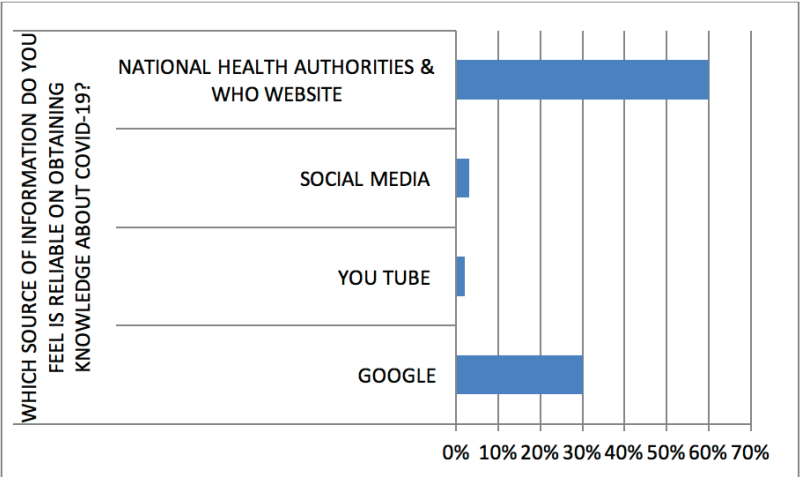

Graph 3 - Source of information on COVID-19.

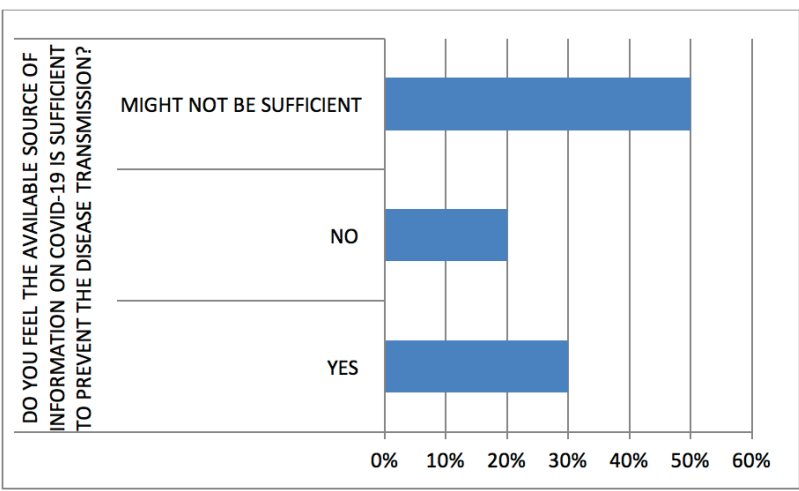

Graph 4 - Availability of information to prevent disease transmission.

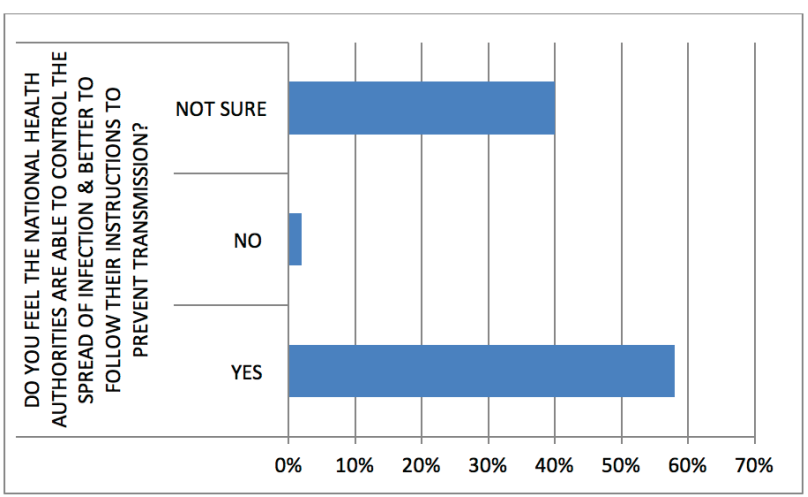

Graph 5 - National health authorities on disease control.

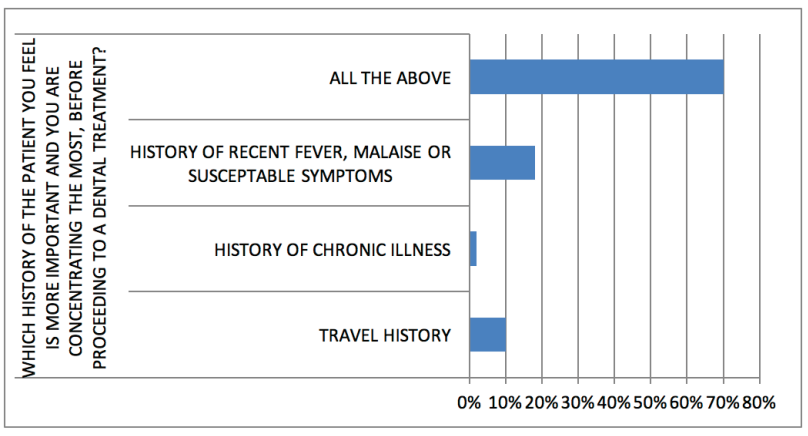

Graph 6 - Patient history in present situation. 


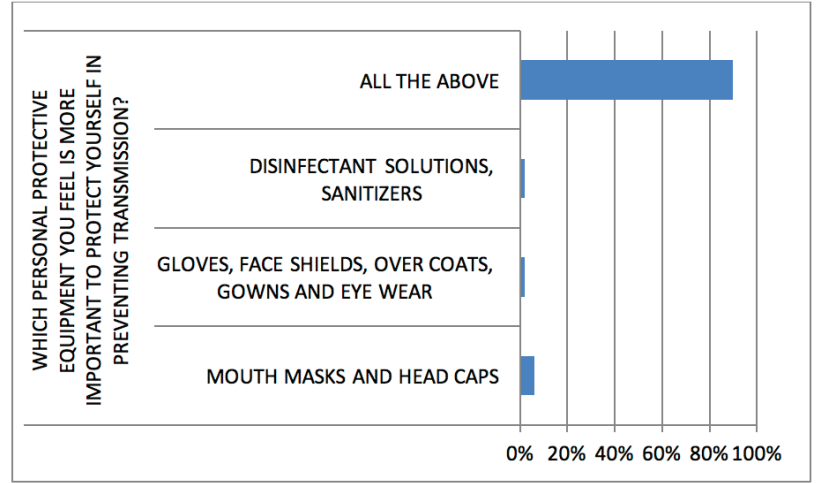

Graph 7 - Information on personal protective equipment used.

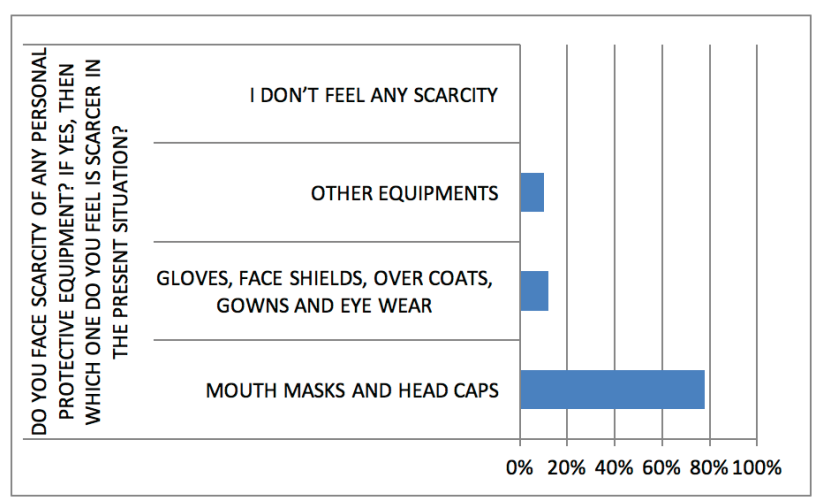

Graph 8 - Scarcity on personal protective equipment.

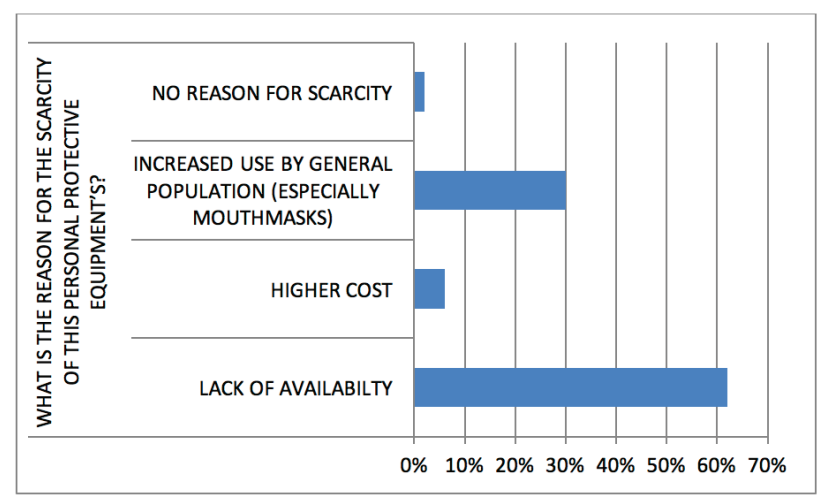

Graph 9 - Reason for scarcity on personal protective equipment.

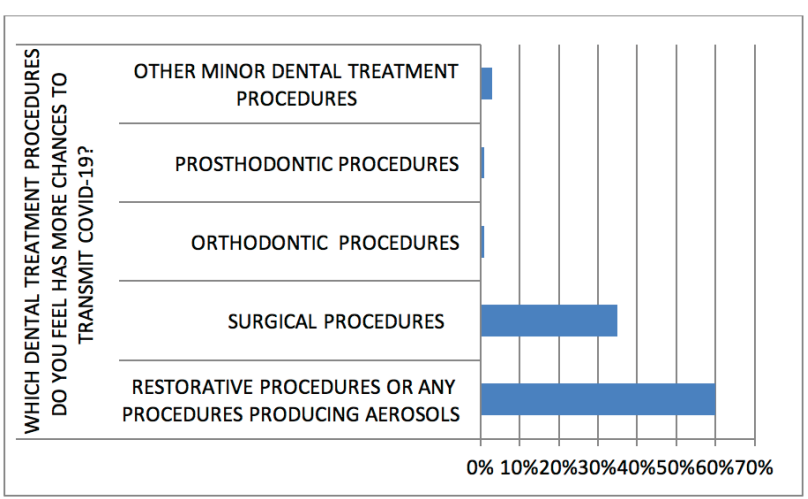

Graph 10 - Dental procedure at higher risk of disease transmission.

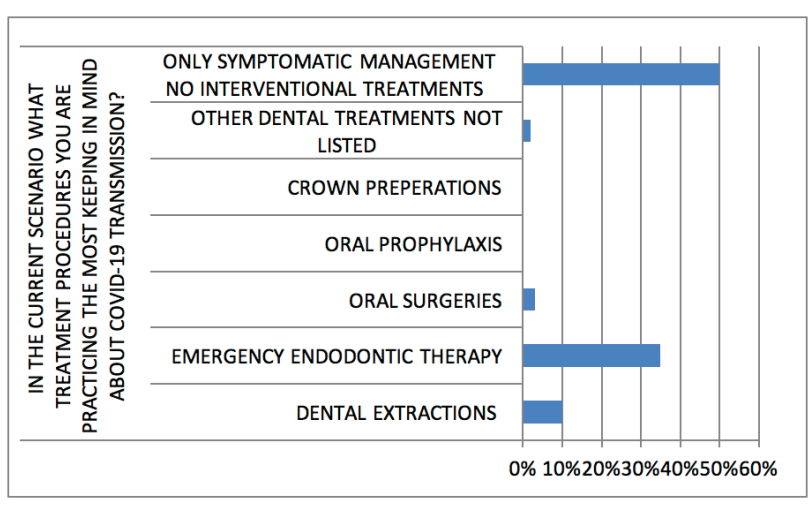

Graph 11 - Current treatments being performed.

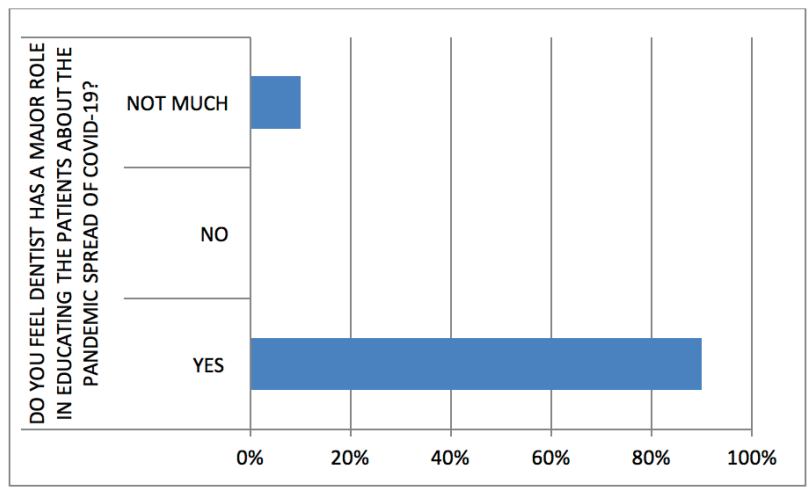

Graph 12 - Dentists role on educating patients on COVID-19. 


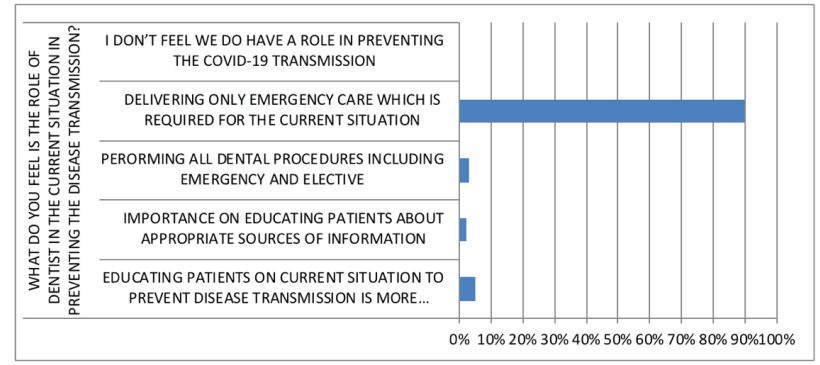

Graph 13 - Role of dentists in current situation.

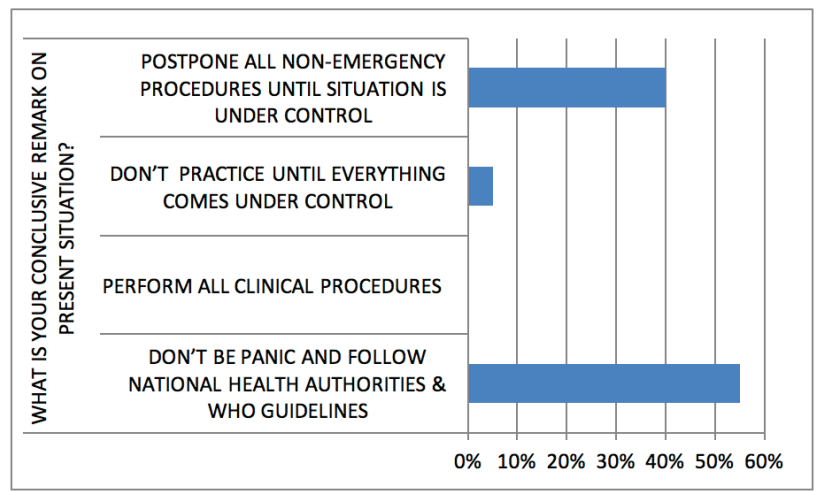

Graph 14 - Conclusive remark on present situation.

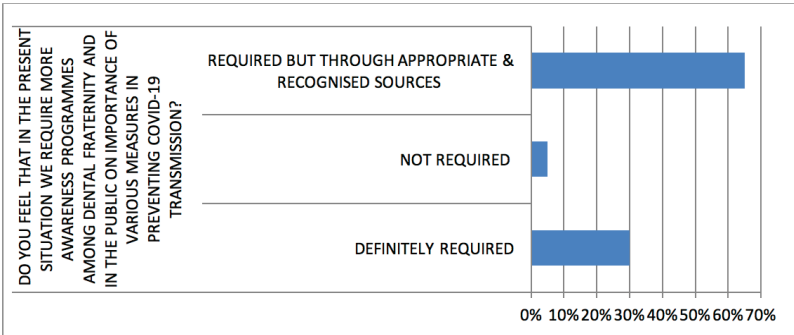

Graph 15 - Requirement of awareness programmes on COVID-19.

\section{RESULTS}

When results of the present survey were analyzed, among 300 participated dentists, 170 had professional experience less than 5 years, 80 of them had 5-10 years of experience, and 50 of them were 10 years experienced.

On analyzing the questionnaire, $60 \%$ of participants were aware that COVID-19 has pandemic spread and is mostly controllable if appropriate sanitization methods and infection control were followed (Graph 1). But, 38\% felt that the spread could not be controllable with the present sanitization methods and infection control. The majority of the dentist's views were in correlation with the information provided by Centre for Disease Control (CDC), which stated that COVID-19 could be mostly prevented from transmission if infection control and appropriate sanitization is followed.[14]

Questionnaire on the health care professionals risk assessment on COVID-19 transmission was analyzed (Graph 2), 40\% of the participants felt that dentists are at higher risk, $50 \%$ of them felt that other health care professionals and nurses are at higher risk of disease transmission. The previous study reports reveal that health care workers are at higher risk of disease transmission due to inhalation of airborne particles and aerosols during dental procedures.[15]

When the reliability of the source of obtained information was asked (Graph 3), $60 \%$ reported keeping in update with National Health Authorities and WHO Websites. But 30\% of participants still rely on Google for updating information on COVID-19.

The majority of the participating dentists around $50 \%$ felt that the available source of information might not be sufficient to prevent disease transmission (Graph 4), whereas 30\% of them thought that the present updated information is adequate.

The majority of the participants, around $58 \%$, felt that National Health Authorities are able to control the infection spread and better to follow their instructions to prevent transmission (Graph 5). 40\% of them were not sure of this aspect.

When they were asked about the information on the important patients they are concentrating on in the day to day practice (Graph 6) majority of the participants around $70 \%$ were concentrating on the history of travel, history of recent acute symptoms, and history of chronic illness. But $40 \%$ of them were mostly concentrating on travel history.

The majority of the dentists around 90\% 
of them felt that personal protective equipment is essential for the prevention of disease of transmission. (Graph 7) The majority of them around $78 \%$ felt the scarcity of mouth masks and head caps. (Graph 8) 62\% of them felt that the shortage was due to lack of availability, but 30\% of the participants thought that it was because of the increased usage by the general population. (Graph 9) The recommendations of infection controls in dental practice as stated by a recent article on transmission routes of $2019-\mathrm{nCoV}$ and controls in dental practice[16,17] stated that, adequate patient evaluation, hand hygiene, appropriate personal protective measures, preoperative mouth rinse before procedures, rubber dam isolation, anti-retraction handpiece, disinfection of clinical settings and appropriate management of medical waste to be followed for disease transmission.

When they were asked about the current treatment procedures practiced the most, keeping COVID-19 transmission prevention, (Graph 10) majority of them around 50\% are doing only the symptomatic managements with no interventional treatments. None of them are performing aerosol procedures such as crown preparations or oral prophylaxis procedures using scalers. Only $35 \%$ of the total participants are delivering emergency endodontic therapies. CDC guidelines state that only emergency interventions to be performed, rescheduling the elective treatment procedures. [16]

$60 \%$ of the participants felt that restorative procedures and any procedures producing aerosols have higher chances to transmit COVID-19. (Graph 11) Only 35\% of them felt that surgical procedures have higher chances in the transmission of infection. A recent article stated that airborne spread by aerosols has higher chances of COVID-19 transmission. [17]

$90 \%$ of the practicing dentists felt that dentists have a major role in preventing the pandemic spread of COVID-19. (Graph 12) $90 \%$ of practicing dentists felt that it is important to deliver only the emergency care which is required for the present situation is more important than performing other elective procedures (Graph 13)

When dentists were asked on the conclusive remark on the current situation, 55\% advised not to be panic and urged to follow National Health Authorities and WHO guidelines. 40\% of them suggested postponing all non-emergency procedures until the situation is under control. (Graph 14) The views were in correlation of CDC recommendation, which stated to postpone non-urgent dental procedures, dental visits and surgeries. [16]

When the questionnaire was asked on the importance of awareness programs among dental fraternity and in public on various measures in preventing COVID-19 transmission, the majority of them around $65 \%$ felt that it is required for such programs, but trough appropriate and recognized sources (Graph 15).

\section{DISCUSSION}

The present survey provides an insight on the knowledge, awareness and practice of dentists in preventing the Novel Corona Virus (COVID-19) transmission at the time of outbreak in 2020. The study was conducted among the practicing dentists of Andhra Pradesh and Telangana states in India. Coronavirus disease (COVID-19) has evolved rapidly into a public health crisis[14] and spread is pandemic to the other parts of the world.[18] The disease transmission is controllable if appropriate infection control and sanitisation protocol is followed in dental practice.[17] In the present study, most of the participating dentists were aware of the pandemic nature of the disease and felt that transmission was controllable on proper infection control and sanitisation.

Owing to the wide spread of transmission of COVID-19, reports state the risk of infection spread among the health care providers. $[19,20]$ Dentists are being highly prone for nosocomial infection and can become potential carriers of the disease.[21] The participating dentists were aware that dentists were at higher risk as other health care professionals. Data sources on the reliability of the information sources 
for Novel Coronavirus (COVID-19) stated the World Health Organisation (WHO) and Centre of Disease Control (CDC) as the best website sources to obtain the reliable information.[22] Most of the dentists were aware on this aspect and around $60 \%$ of the participants referred WHO Websites for obtaining the information on Novel COVID-19. Most of the participants felt that, the available source of information might not be sufficient to prevent the disease transmission.

WHO emphasised public to stay aware on the latest information on the COVID-19 through National health authorities and WHO websites. [23] Most of the participating dentists were updated on latest information on COVID-19 and reported their positive attitude on the importance of national health authorities on disease prevention and control. A recent review article by Ather et al.,[21] has discussed on the patient evaluation during this outbreak and elucidated on the detailed medical history form, COVID-19 screening questionnaire and a true emergency questionnaire forms to rule out the suspected patients. The questionnaire concentrated on the travel history and the history of acute symptoms such as, fever cold and cough along with other history suggestive of high risk individuals. Most of the participants of the present survey were taking the comprehensive medical, dental history along with the travel and other relative history of the patient, which is more appropriate for the current situation.

CDC has given guidelines on the usage of appropriate personal protective equipment including the gloves, goggles and face shields, gown, masks or respirators and maintaining pre and post hand hygiene and sanitisation using disinfectant solutions and alcohol based rubs.[24] Majority of the participating dentists were following the guidelines on the usage of personal protective equipment and hand sanitisation. Around $80 \%$ of the practicing dentists reported the scarcity of mouth masks and head caps in the present situation. Majority of them reported the reason for scarcity was due to the lack of availability of the equipment. Due to the uncertainty of the outbreak, there might be a shortage of personal protective equipment. Therefore, it is advisable to use them judiciously and follow the Centre of Disease Control and Prevention guidelines for N95 respirator use and reuse.[21,24]

Among the accounted dental procedures, restorative procedures and other procedures involving the generation of aerosols have higher chances for COVID-19 transmission. [17] Dentists are being highly prone for disease transmission during dental treatment, due to aerosols generated by various dental procedures on patients with COVID-19.[12] Majority of the participants views are coinciding with the presently available literature evidence. CDC guidelines state that only emergency interventions to be performed, rescheduling the elective treatment procedures.[16] Around $50 \%$ of the dentists were managing patients symptomatically, without any interventional therapy and very few were performing the emergency endodontic procedures. Most of the participating dentists were following the CDC guidelines and they were quite updated with the present scenario.

When views of the participants were asked, majority of them felt that dentists have a role in preventing the Novel COVID-19 transmission and most of them responded that not to be panic on the present situation and follow the guidelines of World Health Organisation (WHO) and National Health Authorities to prevent the disease transmission. Majority of them re-emphasised on delivering only emergency care which is required for the current situation and to postpone all elective procedures until the situation is under control. Finally, around $70 \%$ of the dentists participated felt that awareness programmes are required in the dental fraternity and in the public on the importance of various measures in preventing COVID-19 transmission. So, from overall views of the participating dentists it can be concluded that majority of them were quite updated with the present information on the outbreak and precautionary measures to be followed for the current situation. 


\section{CONCLUSION}

From the present study, it can be concluded that dentists have adequate knowledge of COVID-19 transmission, and the majority of them raised the importance of performing only emergency procedures postponing the elective procedures. Many of them felt that awareness programs are more needed both in dental fraternity and public on COVID-19 prevention.

\section{REFERENCES}

1. The Lancet. Emerging understandings of 2019-nCoV. Lancet. 2020;395(10221):311. doi:101016/S0140-6736(20)30186-0

2. Adhikari SP, Meng S, Wu YJ, Mao YP, Ye RX, Wang QZ, et al. Epidemiology, causes, clinical manifestation and diagnosis, prevention and control of coronavirus disease (COVID-19) during the early outbreak period: a scoping review. Infect Dis Poverty. 2020;9(1):29. Published 2020 Mar 17. doi:10.1186/s40249-020-00646-X

3. Zhu N, Zhang D, Wang W, Li X, Yang B, Song J, et al. Coronavirus from Patients with Pneumonia in China, 2019. N Engl J Med. 2020;382(8):727733. doi:101056/NEJMoa2001017

4. Zhou P, Yang XL, Wang XG, Hu B, Zhang L, Zhang W, et al. Nature. 2020 Mar;579(7798):270-3

5. Ksiazek TG, Erdman D, Goldsmith CS, Zaki SR, Peret T, Emery S, et al. A novel coronavirus associated with severe acute respiratory syndrome. $\mathrm{N}$ Engl J Med. 2003;348(20):1953-1966. doi:10.1056/NEJMoa030781

6. Groot RJ de, Baker SC, Baric RS, Brown CS, Drosten C, Enjuanes L, et al. Middle East respiratory syndrome coronavirus (MERS-CoV): announcement of the Coronavirus Study Group. J Virol. 2013;87(14):77907792. doi:10.1128/JVI.01244-13

7. Wu A, Peng Y, Huang B, Ding X, Wang X, Niu P, et al. Composition and Divergence of the Novel Coronavirus (2019-nCoV) Originating in China. Cell Host Microbe. 2020;27(3):325-328. doi:10.1016/j.chom.2020.02.001

8. Shu Y, McCauley J. GISAID: Global initiative on sharing all influenza data - from vision to reality. Euro Surveill. 2017:22(13):30494. doi:10.2807/1560 7917.ES.2017.22.13.30494

9. Xie X, Li Y, Sun H, Liu L. Exhaled droplets due to talking and coughing JR Soc Interface. 2009;6 Suppl 6(Suppl 6):S703-S714. doi:10.1098/ rsif.2009.0388.focus

10. Chan JFW, Yuan S, Kok KH, To KKW, Chu H, Yang J, et al. A familial cluster of pneumonia associated with the 2019 novel coronavirus indicating person-to-person transmission: a study of a family cluster. Lancet. 2020;395(10223):514-523. doi:10.1016/S0140-6736(20)30154-9
11. Wang D, Hu B, Hu C, Zhu F, Liu X Zhang J, et al Clinical Characteristics of 138 Hospitalized Patients With 2019 Novel Coronavirus-Infected Pneumonia in Wuhan, China [published online ahead of print, 2020 Feb 7]. JAMA. 2020;323(11):1061-1069. doi:10.1001/jama.2020.1585

12. Gamio L. The Workers Who Face the Greatest Coronavirus Risk [Internet]. [cited 2020 Mar 23]. Available at: https://www.nytimes.com/ interactive/2020/03/15/business/economy/coronavirus-worker-risk.html

13. Sabino-Silva R, Jardim ACG, Siqueira WL. Coronavirus COVID-19 impacts to dentistry and potential salivary diagnosis. Clin Oral Investig. 2020;24(4):1619-1621. doi:10.1007/s00784-020-03248-x.

14. Centers for Disease Control and Prevention. Infection Control Guidance for Healthcare Professionals about Coronavirus (COVID-19). Available from: https://www.cdc.gov/coronavirus/2019-ncov/infection-control/index. html

15. Group of Interventional Respiratory Medicine, Chinese Thoracic Society. Zhonghua Jie He He Hu Xi Za Zhi. 2020;43(0):E006. doi:10.3760/ cma.j.issn.1001-0939.2020.0006

16. Centers for Disease Control and Prevention. Releases Interim Reopening Guidance for Dental Settings [Internet]. 2020 [cited 2020 Mar 23]. Available from: https://www.cdc.gov/oralhealth/infectioncontrol/ statement-COVID.html

17. Peng $X, X u X$, Li Y, Cheng L, Zhou X, Ren B. Transmission routes of 2019nCoV and controls in dental practice. Int J Oral Sci. 2020;12(1):9. Published 2020 Mar 3. doi:10.1038/s41368-020-0075-9

18. Dong E, Du H, Gardner L. An interactive web-based dashboard to track COVID-19 in real time. Lancet Infect Dis. 2020;20(5):533-534. doi:10.1016/ S1473-3099(20)30120-1.

19. Wax RS, Christian MD. Practical recommendations for critical care and anesthesiology teams caring for novel coronavirus (2019-nCoV) patients. Directives concrètes à l'intention des équipes de soins intensifs et d'anesthésiologie prenant soin de patients atteints du coronavirus 2019-nCoV. Can J Anaesth. 2020;67(5):568-576. doi:10.1007/s12630-020 01591-x

20. Lan L, Xu D, Ye G, et al. Positive RT-PCR Test Results in Patients Recovered From COVID-19 [published online ahead of print, 2020 Feb 27]. JAMA 2020;323(15):1502-1503. doi:10.1001/jama.2020.2783.

21. Ather A Patel B, Ruparel NB, Diogenes A, Hargreaves KM. Coronavirus Disease 19 (COVID-19): Implications for Clinical Dental Care. J Endod. 2020;46(5):584-595. doi:10.1016/j.joen.2020.03.008.

22. Zawistoski AG. COVID-19: reliable sources for information on the Novel Coronavirus: COVID-19 Information Sources [Internet]. [cited 2020 Jun 8]. Available from: https://libguides.stthomas.edu/c. php?g01010008\&p07317148

23. World Health Organization WHO. Coronavirus disease (COVID-19) advice for the public [Internet]. [cited 2020 Jun 8]. Available from: https://www. who.int/emergencies/diseases/novel-coronavirus-2019/advice-for-public

24. Centers for Disease Control and Prevention. Using Personal Protective Equipment (PPE) [Internet]. [cited 2020 Jun 9]. Available from: https:// www.cdc.gov/coronavirus/2019-ncov/hcp/using-ppe.html

\section{Gummuluri Sriram}

(Corresponding address)

SVS Group of Institutions, SVS School of Pharmacy

Bheemaram, Hanumakonda, Warangal, Telangana, India.

E-mail: ramchinna05@gmail.com

Date submitted: 2020 Jun 06

Accept submission: 2020 Jun 11 